\title{
Optimasi Penyusunan Jadwal Ujian Mata Kuliah Menggunakan Algoritma Genetika Pada Universitas Widya Dharma Pontianak
}

\author{
Haryanto $^{1 *}$, Thommy Willay ${ }^{2}$ \\ ${ }^{1}$ Program Studi Informatika, Universitas Widya Dharma Pontianak \\ ${ }^{2}$ Program Studi Sistem Informasi, Universitas Widya Dharma Pontianak \\ *haryanto@widyadharma.ac.id
}

\begin{abstract}
Scheduling is one of the most common problems in real life. Often the schedule preparation process takes a long time and is not optimal. One of the scheduling arrangements is the preparation of the exam schedule, which in this study uses a case study at the Faculty of Information Technology, Widya Dharma Pontianak University. In the preparation of this exam schedule, it often causes students to bend the student exam schedule, so that it can lead to students taking exams for more than one subject in one day. This will certainly harm students who take the exam, so that students are not optimal in doing the exam. To overcome this problem, a genetic algorithm can be used which helps in preparing the exam schedule. The purpose of this research is to make a schedule for the semester exam using a genetic algorithm, which previously was still compiled manually, so that it can help in making the schedule more optimal and efficient. The results of this research, produce an application that can assist in the preparation of a schedule to be more optimal and efficient, so that there is no longer a schedule for students who take the exam.
\end{abstract}

Keywords: scheduling, artificial intelligence, genetic algorithm

\begin{abstract}
Abstrak
Penjadwalan merupakan salah satu permasalahan yang sering terjadi pada kehidupan nyata. Sering kali proses penyusunan jadwal memakan waktu yang lama dan tidak optimal. Salah satu penyusunan jadwal adalah penyusunan jadwal ujian, yang pada penelitian ini menggunakan studi kasus di Fakultas Teknologi Informasi Universitas Widya Dharma Pontianak. Dalam penyusunan jadwal ujian ini, sering kali menimbulkan bentok mahasiswa jadwal ujian mahasiswa, sehingga dapat menimbulkan mahasiswa yang ujian lebih dari satu mata kuliah dalam satu hari. Hal ini tentu akan merugikan mahasiswa yang mengikuti ujian, sehingga mahasiswa tidak optimal dalam mengerjakan ujian. Untuk mengatasi permasalahan ini, dapat digunakan algoritma genetika yang membatu dalam penyusunan jadwal ujian. Tujuan dari penelitian ini adalah membuat jadwal untuk ujian semester menggunakan algoritma genetika, yang sebelumnya masih menyusun secara manual, sehingga dapat membantu dalam penyusunan jadwal menjadi lebih optimal dan efisien. Hasil dari penelitian ini, menghasilkan sebuah aplikasi yang dapat membantu dalam penyusunan jadwal menjadi lebih optimal dan efisien, sehingga tidak ada lagi bentok jadwal bagi mahasiswa yang mengikuti ujian.
\end{abstract}

Kata kunci: penjadwalan , kecerdasan buatan , algoritma genetika

\section{Pendahuluan}

Penyusunan jadwal merupakan salah satu kegiatan yang sering dilakukan, khususnya pada Perguruan Tinggi. Penyusunan jadwal kadangkala memunculkan permasalahan-permasalahan. Hal ini dapat disebabkan oleh adanya kegiatan mahasiswa, ruang yang terbatas, kegiatan dosen, dan sebagainya. Salah satu kegiatan penyusunan jadwal di Perguruan tinggi adalah penyusunan jadwal ujian semester [1].

Ujian Semester merupakan kegiatan yang dilakukan oleh perguruan tinggi dalam melakukan evaluasi untuk mengukur tercapainya hasil kompetensi belajar mahasiswa dari materi yang diajarkan oleh dosen. Ujian Semester biasanya dilakukan 
sebanyak dua kali yaitu Ujian Tengah Semester (UTS) dan Ujian Akhir Semester (UAS). Dalam pembuatan jadwal ujian ini, harus diperhatikan beberapa hal, sehingga jadwal yang disusun dapat meminimalisir permasalahan-permasalahan ketika jadwal ujian telah disusun.

Pada kampus Universitas Widya Dharma Pontianak, penyusunan jadwal ujian menjadi tanggung jawab ketua panitia ujian. Jadwal yang disusun harus menjamin bahwa mahasiswa yang mengikuti ujian suatu mata kuliah tidak boleh bentrok dengan ujian mata kuliah yang lain. Dengan permasalahan tersebut, penyusunan jadwal ujian harus melihat data regis masing masing mahasiswa.

Penyusunan jadwal mata kuliah yang selama ini dilakukan menggunakan aplikasi Microsoft Office Excel yang peng-input-an dan analisa datanya, seperti pengecekan berapa jumlah mahasiswa yang bentrok jika jadwal tersebut digunakan, dilakukan secara manual. Dengan cara manual tersebut, proses penyusunan jadwal akan memakan waktu cukup lama dan jadwal yang disusun dapat tidak optimal. Ini dikarenakan dibutuhkan ketelitian, terutama saat perkuliahan online, yang biasanya saat perkuliahan tatap muka ujian dapat berlangsung selama dua minggu, saat perkuliahan online ini ujian berlangsung hanya selama 8 hari, yang membuat kemungkinan mahasiswa yang bentrok akan semakin tinggi.

Dibutuhkan sebuah sistem untuk mengatasi permasalahan tersebut. Sistem yang dibangun dapat menyusun jadwal ujian secara otomatis, sehingga penyusunan jadwal dapat efisien dan dapat lebih optimal dalam meminimalisir terjadinya bentrok saat mahasiswa melakukan ujian. Untuk mengoptimalkan sistem tersebut, digunakan suatu algoritma, yaitu Algoritma Genetika. Algoritma Genetika merupakan suatu algoritma pencarian yang didasarkan pada suatu mekanisme seleksi alamiah dan genetika alamiah [2].

Algoritma genetika menggunakan pemahaman mengenai evolusi alamiah pada cara pemecahan masalah [3]. Algoritma genetika biasanya diaplikasikan untuk permasalahan-permasalahan seperti optimasi, learning, peramalan, pemrograman otomatis, dan sebagainya.

Berbagai penelitian tentang algoritma genetika, khususnya tentang optimasi penjadwalan sudah banyak dilakukan. Berikut ini merupakan penelitian-penelitian terkait dengan sistem penjadwalan menggunakan algoritma genetika:

Penelitian yang dilakukan oleh Lian Aga Aditya dan Windha Mega PD pada tahun 2017 dengan judul "Algoritma Genetika Untuk Penjadwalan Mata Pelajaran Pada LMS", menghasilkan kesimpulan bahwa proses penyusunan jadwal menggunakan Algoritma Genetika dapat menghasilkan jadwal yang optimal. Hal ini didasarkan dari perhitungan nilai fitness tertinggi pada saat proses algoritma genetika tersebut dilakukan dan berdasarkan mekanisme Algoritma Genetika yang telah dibuat [4].

Penelitian oleh I Made Budi Adnayana pada tahun 2018 dengan judul "Implementasi Algoritma Genetika untuk Penjadwalan Asisten Dosen di STIKOM Bali", menghasilkan kesimpulan bahwa secara otomatis algoritma Genetika dapat menghasilkan jadwal yang optimal. Penerapan algoritma Genetika pada sistem yang diteliti tersebut diawali dengan proses pembentukan kromosom, populasi, dan penentuan fungsi fitness, dilanjutkan dengan proses seleksi, kawin silang, dan mutase, sehingga menghasilkan individu terbaik [5].

Dilengkapi dengan penelitian oleh Ronny pada tahun 2017 dengan judul "Penjadwalan Satpam Jaga dengan Algoritma Genetika" bahwa penyusunan algoritma genetika dapat menghasilkan dengan lebih mudah dan lebih menghemat waktu daripada menyusun jadwal secara manual. Penyusunan jadwal menggunakan algoritma genetika juga dapat menghasilkan jadwal tanpa adanya bentrok pada jadwal hal ini disebabkan karena pada genetika terdapat proses evaluasi yang berfungsi untuk menilai suatu jadwal, apabila jadwal tersebut memiliki bentrok, maka proses genetika akan berulang lagi [6].

\section{Metoda Penelitian}

Metoda penelitian merupakan serangkaian proses dalam penelitian yang tersusun secara sistematis. Tahapan ini 
bertujuan supaya proses pelaksanaan penelitian akan menghasilkan hasil yang sesuai dengan tujuan penelitian. Berikut tahapan yang akan dilakukan dalam penelitian ini:

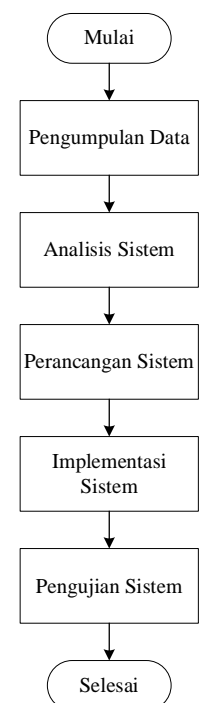

Gambar 1. Metodologi Penelitian

Perancangan sistem ini menggunakan Algoritma Genetika dalam proses penyusunan jadwal ujian. Proses dalam algoritma Genetika ini berdasarkan pada proses genetik yang ada pada makhluk hidup, yaitu proses alami pada perkembangan generasi dalam sebuah populasi yang mengikuti prinsip seleksi alam. Algoritma Genetika ini meniru teori evolusi tersebut, sehingga dapat digunakan di dunia nyata untuk mencari solusi dari permasalahanpermasalahan yang ada [7].

\subsection{Rancangan Penelitian}

Rancangan Penelitian yang digunakan penulis dalam penelitian ini adalah penelitian deskriptif, yang membuat deskripsi secara sistematis, factual, dan akurat mengenai fakta-fakta yang terjadi pada objek penelitian.

\subsection{Pengumpulan Data}

Pengumpulan data ini dilakukan dengan mengumpulkan data berupa regis mahasiswa, data mata kuliah, dan data untuk pembuatan fungsi fitness. Metode pengumpulan data yang dilakukan adalah dengan mengumpulkan informasi dari dari observasi atau wawancara.

\subsection{Teknik Analisis Sistem}

Data yang telah dikumpulkan selanjutnya adakan dilakukan analisis. Analisis tersebut terdiri dari analisis data masukan, analisis dari model algoritma genetika yang akan dibangun, serta Analisis data keluaran.

\subsubsection{Analisa data masukan}

Analisa data masukan (input), bertujuan untuk mengidentifikasi masukan (input) yang dibutuhkan oleh sistem.

\subsubsection{Analisa model dari Algoritma Genetika}

Algoritma genetika biasanya digunakan untuk penyelesaian permasalahan yang tidak memiliki metode penyelesaian dengan rumusan yang tepat, dan jika ada perumusannya, dibutuhkan waktu yang cukup lama untuk menyelesaikannya. Permasalahan tersebut seringkali sangat beragam dan kompleks. Algoritma Genetika digunakan dalam penyusunan jadwal ujian untuk membantu dalam penyelesaian permasalahan tersebut [8].

Parameter genetika meliputi jumlah generasi (iterasi) yang digunakan sebagai batasan untuk menghindari proses iterasi yang tak terhingga. Ukuran populasi menunjukkan banyaknya populasi awal yang akan dijadikan sebagai induk. Crossover dan mutasi merupakan proses pembentukan populasi baru. Nilai pada parameter genetika disesuaikan untuk mendapatkan hasil yang optimal ditunjukkan pada Tabel 1 [9].

Tabel 1. Parameter Genetika

\begin{tabular}{ccc}
\hline No. & Keterangan & Jumlah \\
\hline 1 & Generasi (iterasi) & 250 \\
2 & Populasi & 10 \\
3 & Crossover (kawin silang) & 0,7 \\
4 & Mutasi & 0,3 \\
\hline
\end{tabular}

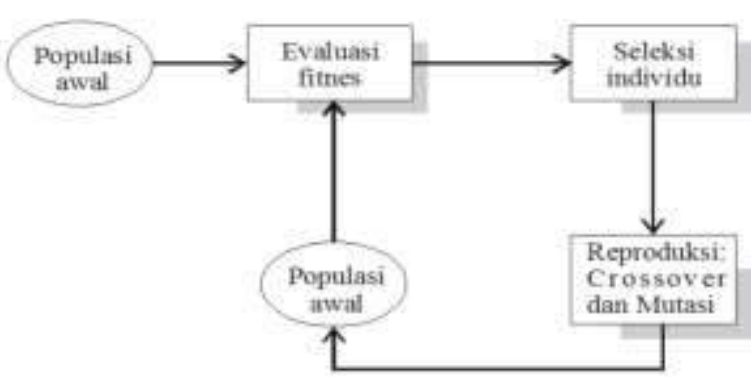

Gambar .2 Siklus Algoritma Genetika

Algoritma Genetika memiliki beberapa komponen, antara lain: skema pengkodean, 
penentuan fungsi fitness, seleksi, crossover (kawin silang), proses mutasi, Elitisme, penggantian populasi untuk mencari individu terbaik, dan kriteria penghentian iterasi.

\subsubsection{Skema Pengkodean}

Skema pengkodean merupakan proses pendefinisian suatu individu yang dibentuk dalam bentuk suatu kromosom. Skema pengkodean meliputi inisiasi kromosom berupa bentuk kromosom dan gen. Nilai dari kromosom ditentukan secara acak dan akan disesuaikan dengan nilai maksimal dari kromosom tersebut.

\subsubsection{Nilai Fitness}

Nilai fitness dalam algoritma genetika merupakan nilai individu, yang menentukan individu tersebut baik atau tidak. Semakin tinggi nilai fitness suatu individu, maka semakin baik individu tersebut. Individu terbaiklah yang akan dapat bertahan hidup, sedangkan individu yang bernilai fitness terkecil akan mati. Penentuan suatu nilai Fitness, diperoleh dari suatu fungsi.

\subsubsection{Seleksi}

Proses seleksi digunakan untuk untuk menentukan individu-individu yang selanjutnya akan dipilih untuk dilakukan crossover (kawin silang). Salah satu metode seleksi yang biasanya digunakan adalah metode turnamen. Sesuai dengan namanya, metode ini akan membentuk sebuah turnamen dengan pembagian dua buah sisi. Suatu individu dalam populasi, akan dipilih secara acak dan ditempatkan ke masing-masing sisi. Dari masing-masing sisi tersebut, dipilih individu terbaik. Sehingga individu terbaik masing-masing sisi tersebut, selanjutnya akan dilakukan proses kawin silang.

\subsubsection{Kawin Silang}

Proses kawin silang merupakan proses untuk menghasilkan variasi genetik dari suatu populasi. Terjadi kombinasi pewarisan gengen dari induknya pada saat proses kawin silang ini. Gen-gen dari kedua induk akan bercampur sehingga menghasilkan susunan kromosom yang baru.

\subsubsection{Mutasi}

Pada proses mutasi, suatu gen dalam kromosom akan diubah nilainya. Mutasi akan menciptakan individu baru dengan cara melakukan modifikasi satu atau lebih gen dalam suatu individu. Proses modifikasi ini dapat berupa proses pertukaran suatu gen dalam kromosom atau proses mengubah nilai dalam suatu kromosom. Pada penelitian ini, proses mutasi yang dilakukan adalah proses pertukaran gen dalam kromosom.

\subsubsection{Elitisme}

Suatu proses kawin silang dan mutase, tidak menjamin bahwa suatu individu akan bernilai fitness lebih baik daripada induknya. Sehingga untuk menjaga induk dengan nilai fitness tinggi tidak tergantikan oleh individu baru yang bernilai fitness lebih rendah, maka diperlukan untuk menyimpan sementara induk yang dengan nilai fitness tertinggi. Prosedur ini dikenal sebagai elitism.

\subsubsection{Penggantian Populasi}

Proses penggantian populasi merupakan proses penggantian individu pada suatu generasi, yang digantikan oleh individu baru hasil kawin silang dan mutasi.

\subsubsection{Kriteria Penghentian}

Algoritma genetika merupakan proses yang akan melakukan iterasi terus menerus. Sehingga diperlukan suatu kriteria untuk menghentikan iterasi tersebut.

\section{Hasil Penelitian}

\subsection{Pengkodean}

Pengkodean yang digunakan adalah pengkodean nilai. Dari hasil observasi yang dilakukan, model kromosom yang dibuat adalah sebanyak empat buah kromosom yang merepresentasikan masing-masing semester, dengan gen sebanyak delapan buah yang merepresentasikan hari, yaitu sebanyak delapan hari ujian. Nilai dari Gen merepresentasikan kode mata kuliah. Kromosom ini digambarkan dengan gambar 1

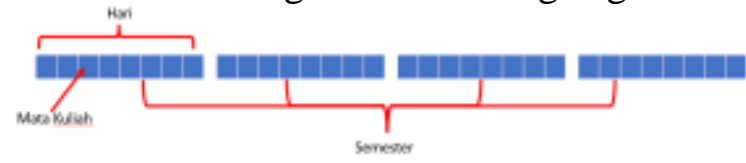

Gambar 3. Pengkodean Jadwal Ujian 


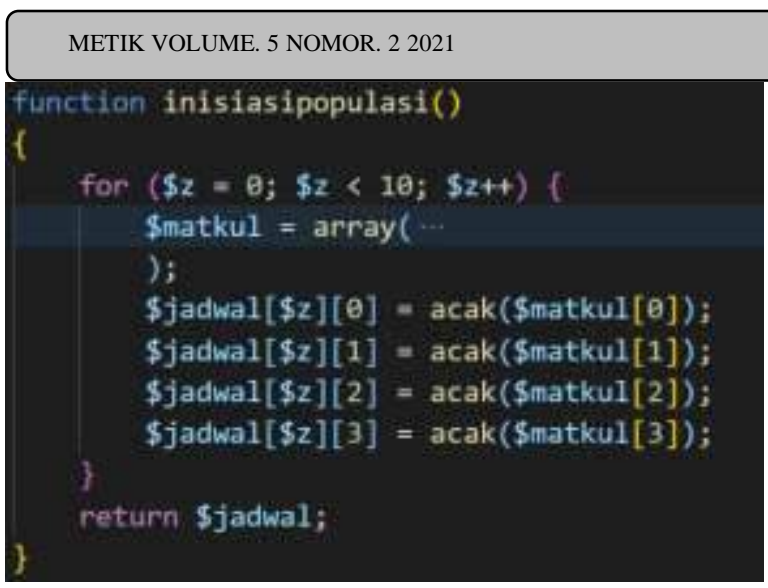

Gambar 4. Code Inisialisasi Populasi

\subsection{Fungsi Fitness}

Setiap aturan yang dipergunakan dalam penyusunan jadwal ujian diberi nilai penalti. Dari hasil observasi, Perkuliahan di universitas Widya Dharma Pontianak, terdapat dua buah sesi perkuliahan, yaitu sesi Pagi dan Sore. Sehingga terdapat dua buah kriteria untuk pemberian nilai penalti, yaitu pertama mahasiswa yang ujian mata kuliah di sesi yang sama, hal ini harus dihindari, sehingga nilai penalti yang diberikan akan besar, kedua yaitu untuk mahasiswa yang ujian pada sesi yang berbeda, yaitu mahasiswa yang ujian di perkuliahan sesi Pagi, dan mahasiswa yang ujian di perkuliahan sesi Sore. Untuk permasalahan ini, nilai penalti yang diberikan tidak cukup besar, dikarenakan bentrok ujian ini tidak akan mengganggu waktu ujian di kedua mata kuliah tersebut.

Fungsi fitness yang digunakan adalah

$$
\text { Fitness }=1 /\left(1+\sum_{i=1}^{n} \text { aturan }_{i} \times \text { pinalti }_{i}\right.
$$

Tabel 2. Nilai Pinalti

\begin{tabular}{ccc}
\hline No. & Aturan & Nilai Penalti \\
\hline 1 & Bentrok Pada Sama Sesi & 10 \\
2 & Bentrok Berbeda Sesi & 0,5 \\
\hline
\end{tabular}

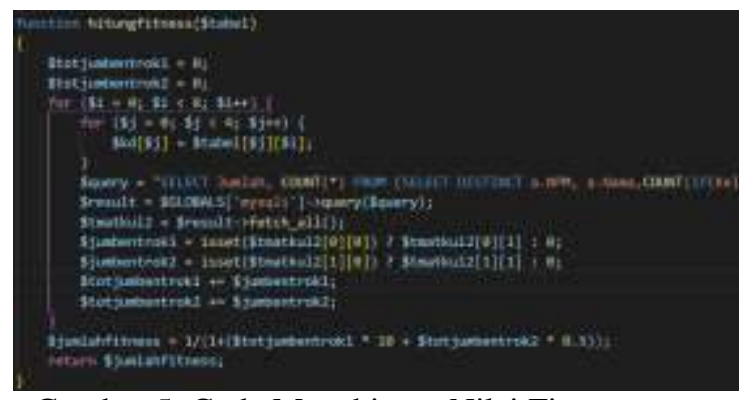

Gambar 5. Code Menghitung Nilai Fitness

\subsection{Seleksi}

ISSN-P 2442-9562

ISSN-E 2580-1503

Pada proses ini induk (parent) akan dipilih, yang selanjutnya akan digunakan untuk menghasilkan generasi baru. Metode seleksi yang digunakan dalam proses penjadwalan ujian ini adalah proses seleksi turnamen. Pada metode suatu populasi akan dibagi dua secara acak, masing-masing bagian individu yang memiliki nilai fitness terbaik yang akan dipilih. Kedua individu tersebut selanjutnya akan dilakukan kawin silang.

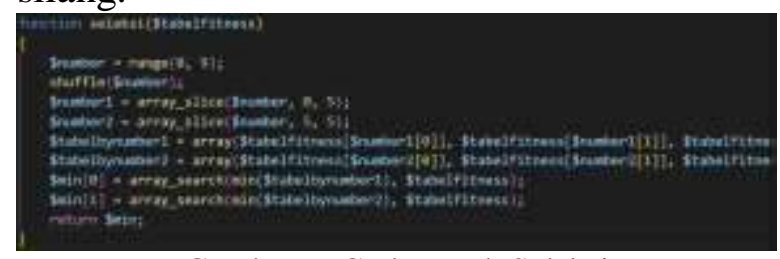

Gambar 6. Code untuk Seleksi

\subsection{Kawin Silang}

Proses kawin silang ini, kromosom pada dua induk yang dipilih pada posisi yang sama akan dilakukan pertukaran nilai. Setelah pertukaran terjadi, maka akan terbentuk dua individu baru, kedua individu baru tersebut akan dilakukan pengecekan kembali untuk mengetahui kromosom baru yang tersebut pembentukannya sudah sesuai dengan aturan yang berlaku atau belum. Untuk posisi yang akan dilakukan penukaran, posisi tersebut dipilih secara acak.

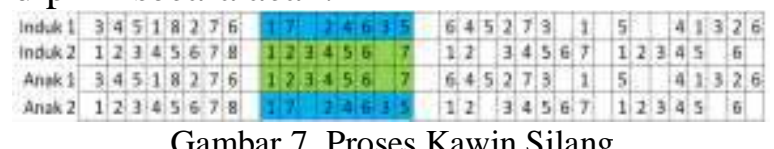

Gambar 7. Proses Kawin Silang

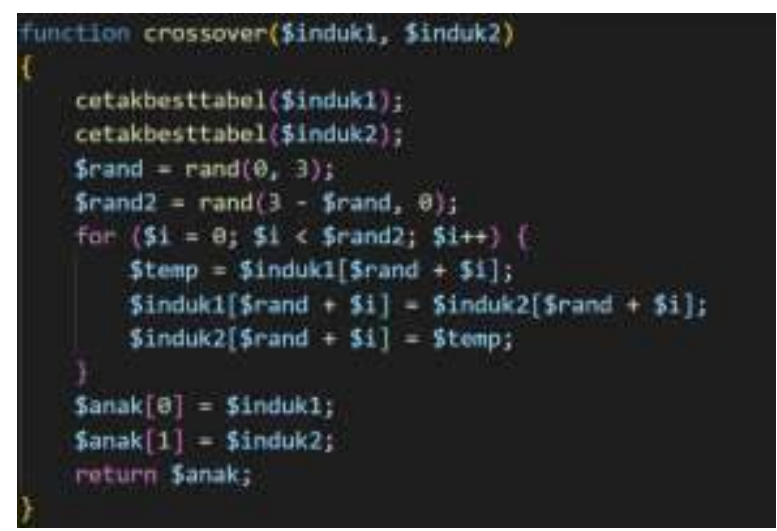

Gambar 8. Code Untuk Crossover

\subsection{Mutasi}

Proses Mutasi dilakukan dengan penukaran dua gen dalam satu kromosom secara langsung. Proses mutasi dalam penjadwalan ini akan dilakukan dengan cara 
acak begitu juga gen yang akan ditukar juga dipilih secara acak.

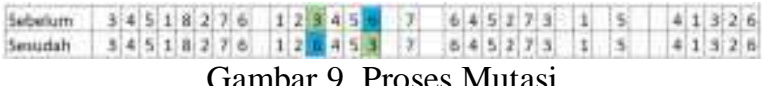

Gambar 9. Proses Mutasi

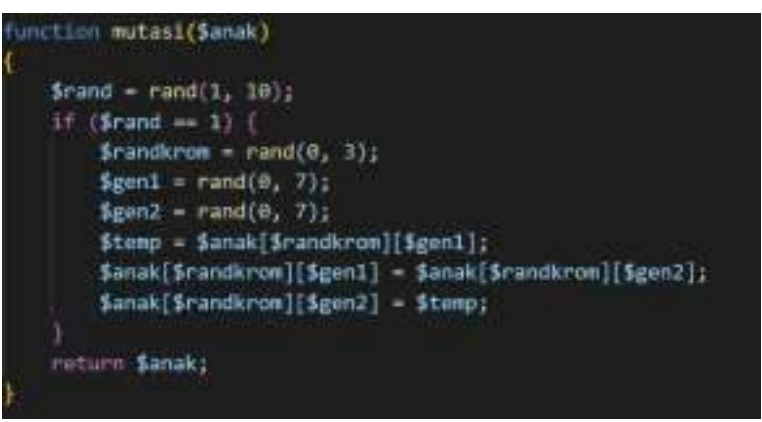

Gambar 10 Code Untuk Mutasi

\subsection{Proses Penggantian Populasi}

Proses penggantian populasi dilakukan setelah didapatkan dua buah anak yang telah melalui proses kawin silang. Anak-anak tersebut akan dihitung nilai fitness-nya masing-masing, jika nilai fitness anak tersebut lebih baik daripada induknya, maka anak tersebut akan menggantikan induknya, sedangkan jika induk masih lebih baik dari anaknya, maka induk tersebut akan tetap berada dalam populasi.

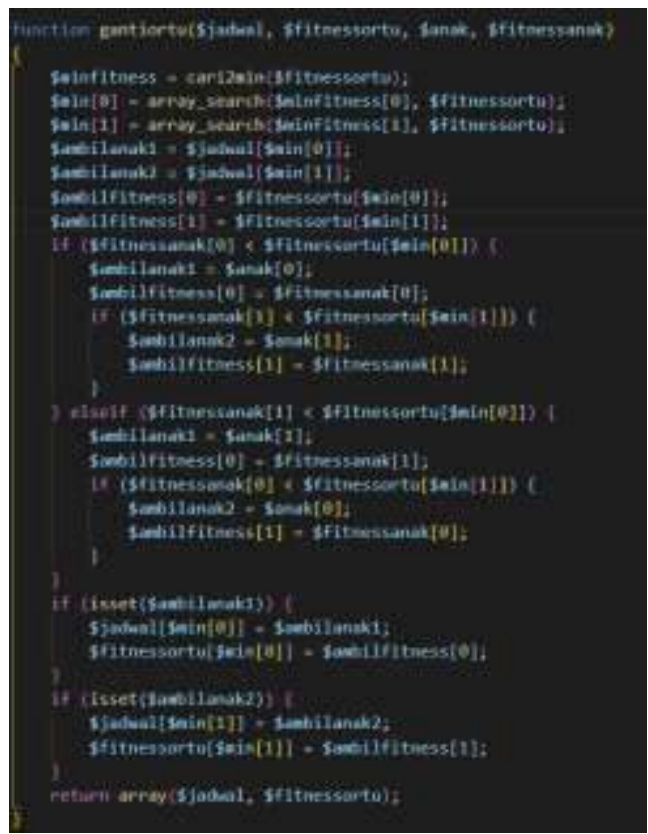

Gambar 11. Code Untuk Pergantian Populasi

\subsection{Proses Penghentian Populasi}

Proses penghentian populasi terjadi jika beberapa kriteria telah terpenuhi, antara lain: pertama jika Batasan jumlah iterasi sudah tercapai, kedua, jika selama beberapa generasi tidak terjadi perubahan nilai fitness terbaik. Untuk penelitian ini, proses penghentian populasi menggunakan parameter jumlah iterasi sebanyak 250 generasi dan jumlah Batasan generasi berhenti jika tidak terjadi perubahan individu adalah sebanyak 25 generasi.

\section{Hasil Analisis Data}

Hasil yang terbentuk dari sistem penjadwalan ujian adalah berupa jadwal ujian selama delapan hari.

Untuk mendapatkan jadwal jadwal yang optimal, penulis melakukan lima kali percobaan algoritma genetika dengan hasil fitness terbaik sebanyak lima kali percobaan adalah

\begin{tabular}{|l|l|l|l|l|}
\hline Percobaan 1 & Percobaan 2 & Percobaan 3 & Percobaan 4 & Percobaan 5 \\
\hline
\end{tabular} \begin{tabular}{|l|l|l|l|l|l|l|}
\hline 0.00074239 & 0.000825083 & 0.000573394 & 0.000609756 & 0.000652316 \\
\hline
\end{tabular}

Gambar 12. Hasil Uji Coba Sebanyak 5 Kali

Hasil uji coba yang dilakukan, menghasilkan tabel jadwal ujian dengan nilai fitness tertinggi adalah 0,000825083.

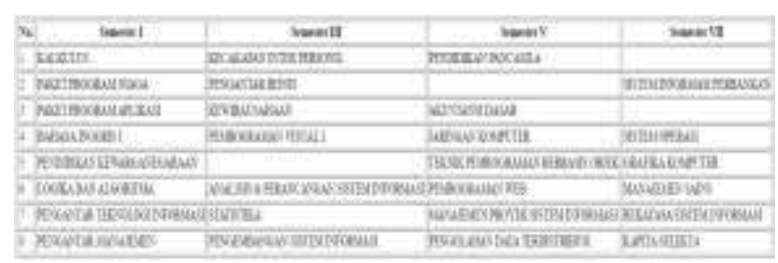

Gambar 13. Hasil dari Algoritma Genetika

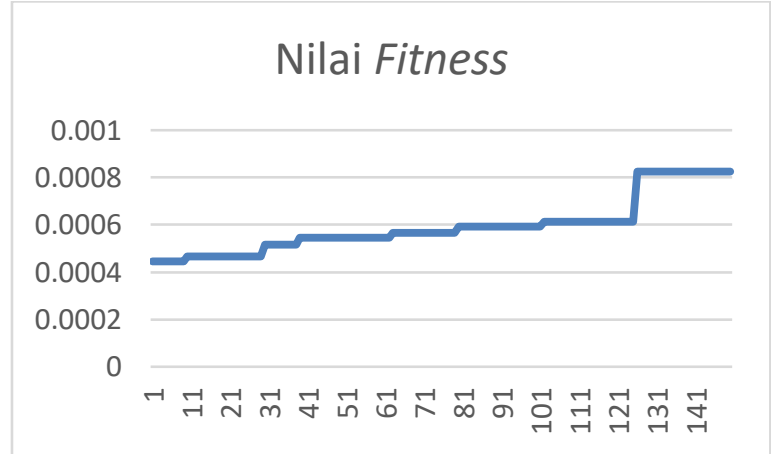

Gambar 14. Grafik Perubahan Fitness

Dari data di atas, terlihat bahwa hasil iterasi generasi pada Algoritma Genetika berhenti di iterasi ke 150 dari yang seharusnya berhenti di iterasi ke 250, ini terjadi dikarenakan tidak terjadi perubahan fitness 
terbaik selama 25 generasi, sesuai dengan proses pemberhentian yang telah diatur.

Dari jadwal yang telah disusun menggunakan algoritma genetika, masih terdapat beberapa mahasiswa yang bentrok sebanyak 7 mahasiswa yang bentrok pada sesi yang sama, dan 50 mahasiswa yang bentrok pada sesi yang berbeda.

\section{Kesimpulan}

Dari proses penyusunan jadwal menggunakan algoritma genetika, sistem dapat menghasilkan jadwal yang yang cukup optimal dan panitia ujian dapat lebih efisien dalam menyusun jadwal. Yang sebelumnya memakan waktu yang cukup lama dalam penyusunan jadwal, dengan algoritma genetika ini dapat membantu dalam penyusunan jadwal menjadi lebih cepat. Serta dapat mencegah tersusunnya jadwal yang memiliki jadwal ujian mahasiswa yang bentrok.

\section{Saran}

Saran yang akan disampaikan untuk pengembangan penelitian ini sebagai berikut:

a. Penelitian penyusunan jadwal ujian menggunakan algoritma genetika ini dapat dikembangkan menjadi lebih baik lagi.

b. Penelitian penyusunan jadwal ujian ini dapat dikembangkan lagi dengan metode menggunakan algoritma genetika dengan parameter-parameter yang lebih baik lagi atau dengan metode algoritma lainnya

\section{Daftar Pustaka}

[1] Ivan, S. Raphael and H. Agung, "Aplikasi Penjadwalan Mata Pelajaran Di SMAN 31 Menggunakan Algoritma Genetika Berbasis Web," Jurnal SIMETRIS, vol. 9, no. 1, pp. 641-656, 2018.
[2] Suyanto,

Artificial

Intelligence:

Searching, Reasoning, Planning, dan Learning, 2014.

[3] S. F. Pane, R. M. Awangga, E. V. Rahcmadani and S. Permana, "Implementasi Algoritma Genetika Untuk Optimalisasi Pelayanan," Jurnal Tekno Insentif, vol. 13, no. 2, pp. 36-43, 2019.

[4] L. A. Aditya and W. . M. PD, "Algoritma Genetika Untuk Penjadwalan Mata Pelajaran Pada LMS," Jurnal Manajemen dan Informatika Pelita Nusantara, vol. 21, no. 1, pp. 65-70, 2017.

[5] I. M. B. Adnyana, "Implementasi Algoritma Genetika untuk Penjadwalan," Jurnal Sistem dan Informatika, vol. 12, no. 2, pp. 166-173, 2018.

[6] Ronny, "Penjadwalan Satpam Jaga dengan Algoritma Genetika," Proxies: Jurnal Informatika, vol. 1, no. 2, pp. 5460, 2017.

[7] A. Amrulloh and E. I. Sela, "Optimasi Proses Penjadwalan Mata Kuliah Menggunakan Algoritma Genetika," Jurnal Teknologi dan Sistem Komputer, vol. 9, no. 3, pp. 157-166, 2021.

[8] A. Qoiriah, "Penjadwalan Ujian Akhir Semester Dengan Algoritma Genetika (Studi Kasus Jurusan Teknik Informatika Unesa)," Jurnal Manajemen Informatika, vol. 3, no. 2, pp. 33-38, 2014.

[9] B. D. Putranto, E. Utami and A. Sunyoto, "Perancangan Sistem Penjadwalan Ujian Menggunakan Algoritma Genetika Pada Stmik Amikom Purwokerto," Jurnal Telematika, vol. 10, no. 2, pp. 106-120, 2017. 